\title{
Risk factors for anemia after one year of kidney transplantation
}

\author{
Ismael Quezada Adame ${ }^{1}$, Ramón Espinoza Pérez ${ }^{2}$, José Cruz Santiago ${ }^{3}$, María de la Luz Sevilla González ${ }^{4}$, Rodolfo Rivas Ruiz ${ }^{5}$ Genaro Ángel \\ Cuazochpa Delgadillo ${ }^{6}$, Blanca Estela Herrera Morales ${ }^{6}$, Ana Yadira Bermúdez González $z^{6}$ Efraín Absalón Medina Villaseñor ${ }^{7}$ and Juan Carlos H \\ Hernández Rivera ${ }^{8 *}$ \\ ${ }^{1}$ Hospital coordination of organ and tissue donation for transplantation purposes. Regional General Hospital 196, Mexican Institute of Social Security, Ecatepec, \\ State of Mexico, Mexico \\ ${ }^{2}$ Renal Transplant Unit, National Medical Center “XXI Century”, Mexican Institute of Social Security, Mexico City, Mexico \\ ${ }^{3}$ Renal Transplant Unit, National Medical Center Specialties Hospital "La Raza”, Mexican Institute of Social Security, Mexico City, Mexico \\ ${ }^{4}$ Section of Postgraduate Studies and Research. National Polytechnic Institute, Mexico City, Mexico \\ ${ }^{5}$ Clinical Research Training Center (CAIC), Health Research Coordination, National Medical Center "XXI Century", Mexican Institute of Social Security, Mexico \\ City, Mexico \\ ${ }^{6}$ Hospital General Regional Hospital 196 “Fidel Velázquez Sánchez”, Mexican Institute of Social Security, Ecatepec, State of Mexico, Mexico \\ ${ }^{7}$ Betania Medical Specialties, Los Reyes Acaquilpan, State of Mexico, Mexico \\ ${ }^{8}$ Unit of Medical Research in Nephrological Diseases, National Medical Center Specialties Hospital "XXI Century”, Mexican Institute of Social Security, Mexico \\ City, Mexico
}

\begin{abstract}
Post renal transplant anemia (PTA) occurs in one out of every four patients and, by itself, increases mortality by six times at 10 years. The risk factors associated with its presence, during the first year, have been reported in some investigations with populations, generally different from Latin America. Therefore, a retrospective, longitudinal study was carried out that included 1,438 kidney transplant patients over six years in two public Medical Centers in Mexico. There were 39 deaths (2.7\%) and 44 graft losses (3.1\%) before one year of follow-up, who left the study. In the 1,355 cases that continued, a prevalence of anemia of $15.5 \%$ ( $\mathrm{n}=210$ ) was found at 12 months. In the bivariate analysis with the PTA at one year, the cadaveric origin of the graft resulted in an OR of 2.24, 95\% CI (1.65-3.05) and for creatinine $(\mathrm{Cr})>2.0 \mathrm{mg} / \mathrm{dL}$ at 6 months, OR of 4.18, 95\% CI (2.66-6.56). With Cr> 2.0mg / dL; At 12 months, an OR of 5.55 was obtained, 95\% CI (3.66-8.42). Height, baseline $\mathrm{Cr}$, as well as female sex, had a statistically significant relationship with the outcome. In the multivariate model performed, the cadaveric donor, the female sex, and the $\mathrm{Cr}>2.0 \mathrm{mg} / \mathrm{dL}$ at 6 and 12 months predicted anemia at one year. It is concluded that $\mathrm{Cr}>2.0 \mathrm{mg} / \mathrm{dL}$, the female sex and the cadaveric graft are the main risk factors for anemia, one year after kidney transplantation.
\end{abstract}

Abbreviations: PTA: Post renal transplant anemia; Cr: Creatinine; Hb: Hemoglobin; KT: Kidney Transplantation; EPO: Erythropoietin; ACEIs: Angiotensin converting enzyme inhibitors; ARA II: Angiotensin II receptor antagonists; BMI: Body mass index; GFR: glomerular filtration rate

\section{Introduction}

Compared with other replacement therapies, kidney transplantation (KT) has offered the best results in the patient's living condition and survival [1-4], however, it is not without complications. One of them is anemia, which is usually present in patients with advanced stages of kidney damage. This condition is correctable, in most cases, with KT, however, when it is not achieved, it negatively influences the function, conservation and survival of the kidney graft [5-14] due to its effect at the cardiovascular level.

The prevalence of post renal transplant anemia (PTA) is $80 \%$ in the first month after surgery, reducing to $20 \%$ in the first year $[15,16]$.

The causes include age, sex, type of donor (living or cadaveric), surgical bleeding, hemodilution, lack of erythropoietin (EPO) production, iron or folate deficiency, parvovirus infections; neoplasms, hypoalbuminemia, use of angiotensin converting enzyme inhibitors (ACEIs) and angiotensin II receptor antagonists (ARA II); inflammatory processes secondary to autoimmune diseases, antibodies against erythropoietin (alpha and beta); immunosuppressants, antibiotics, antivirals, and immunoglobulin treatment [17-22]. Likewise, serum creatinine values above $2 \mathrm{mg} / \mathrm{dL}$ decrease the erythropoietin produced by the transplanted kidney, as well as its effect on the pro-erythroblast, promoting the persistence of anemia $[23,24]$. It should be noted that, in studies with analysis adjusted to age, gender and stage of kidney disease, an increase in the risk of mortality was observed with moderate (HR 6.16, 95\% CI 1.12-34.33, $\mathrm{p}=0.038$ ) and severe (HR 9.79, 95\% CI $2.57-37.26, \mathrm{p}=0.001)$ [25], after 10 years of follow-up.

*Correspondence to: Juan Carlos H Hernández Rivera, Hernández RJCH, Av. Cuauhtémoc 330, Colonia Doctores, México, DF, CP 06722, Tel: 5559664384; E-mail: juancarloshhernandezrivera@hotmail.com

Key words: anemia, kidney transplant, risk factors

Received: March 24, 2021; Accepted: March 29, 2021; Published: April 01, 2021 
Considering that in Latin America there are few publications in this regard, the present study was carried out in order to identify risk factors for PTA, at one year in a Mexican population.

\section{Methods}

This is a retrospective, longitudinal study, carried out in the transplant units of two public Medical Centers, of the Mexican Institute of Social Security (IMSS), from January 2013 to January 2019. All transplant patients were included in the period established, excluding those who did not have complete data on the variables under study. Those who did not complete the one-year follow-up due to death or graft loss were eliminated.

The data was obtained from electronic medical records, on institutional virtual platforms. The main outcome was anemia at one year of follow-up after transplantation, presented as a dichotomous variable. Among the variables considered in the baseline analysis, anemia prior to transplantation was categorized as: absent, mild and severe. Similarly, replacement therapy prior to graft, as a polytomous variable, was divided into: anticipated, when there was no replacement therapy, dialysis (peritoneal) and hemodialysis.

Kolmogorov-Smirnov normality tests were applied to all the variables considered, applying the relevant test for each one: Pearson, Spearman and Chi-square; Correlation was sought and OR with $95 \%$ CI was calculated. For the multivariate analysis, a logistic regression model was developed with all the variables, leaving in the final model those that had the greatest statistical significance in the bivariate. In all the tests carried out, a value of $p$, less than 0.05 , was considered for bilateral significance.

The study was accepted by the IMSS National Research Ethics Committee, considering it a risk-free study.

\section{Results and Discussion}

From the universe, made up of 1608 subjects, 170 were excluded, with incomplete data, leaving 1438 cases, in whom the characteristics and secondary outcomes were analyzed (Table 1), finding, before completing one year of follow-up, 39 deaths $(2.7 \%)$ and 44 graft losses (3.1\%), which were eliminated from the study.

In the population that presented the main outcome $(\mathrm{N}=1355)$, comparing the groups with and without anemia, at one year of followup, an OR of 2.24 was found for the cadaveric donor, 95\% CI (1.653.05). Creatinine above $2.0 \mathrm{mg} / \mathrm{dL}$, at 6 months, had OR of $4.18,95 \% \mathrm{CI}$ (2.66-6.56), while for creatinine greater than $2.0 \mathrm{mg} / \mathrm{dL}$, at 12 months, an OR of 5.55, 95\% CI (3.66-8.42) (Figure 1). The rest of the results are shown in Table 2.

When developing a regression model in which the variables with statistical significance were included in the bivariate, the type of donor, sex, as well as creatinine at six and twelve months were taken for a final model (dichotomous with cut-off at $2.0 \mathrm{mg} / \mathrm{dL}$.), (Table 3).

We found that the factors associated with PTA at one year of followup were: height, baseline creatinine, creatinine at the third, sixth and twelfth month; increasing the risk for women, cadaveric donor, serum creatinine above $1.2 \mathrm{mg} / \mathrm{dL}$ at the sixth and twelfth month, as well as creatinine above $2.0 \mathrm{mg} / \mathrm{dL}$ at the third, sixth and twelfth month. The cadaveric donor, female sex, and creatinine above $2.0 \mathrm{mg} / \mathrm{dL}$, at six and 12 months, were distinguished as predictors of PTA, as a whole.

Mortality and graft loss, as secondary outcomes before one year of post-transplant follow-up, occurred in $2.7 \%$ and $3.1 \%$, respectively.
Table 1. Characteristics of kidney transplant population

\begin{tabular}{|c|c|}
\hline Characteristics & Patients Incluided $\quad \mathrm{N}=1438$ \\
\hline $\begin{array}{l}\text { Hospital } \\
1 \\
2\end{array}$ & $\begin{array}{l}832(57.9) \text { " } \\
606(42.1)^{*}\end{array}$ \\
\hline $\begin{array}{l}\text { Sex } \\
\text { Female } \\
\text { Male }\end{array}$ & $\begin{array}{l}603(41.9) \\
835(58.1)\end{array}$ \\
\hline $\begin{array}{l}\text { Donor } \\
\text { Cadaveric } \\
\text { Living } \\
\end{array}$ & $\begin{array}{l}383(26.6)^{*} \\
1055(73.4)^{*}\end{array}$ \\
\hline Retrasplant & $47(3.3)^{*}$ \\
\hline $\begin{array}{l}\text { Pre-transplant replacement therapy } \\
\text { anticipated } \\
\text { dialysis } \\
\text { hemodialysis }\end{array}$ & $\begin{array}{l}189(13.1)^{*} \\
688(47.8)^{*} \\
561(39)^{*}\end{array}$ \\
\hline Age, in years & $30(25,41)^{\&}$ \\
\hline Weight, in kilograms & $62(53.37,71)^{\&}$ \\
\hline Size, in meters & $1.61(1.55,1.69)$ \& \\
\hline Body mass index & $23.5(21.2,26.06)^{\&}$ \\
\hline Pre-transplant creatinine, in milligrams/deciliter & $11.6(8.33,15.2)^{\&}$ \\
\hline Pre-transplant hemoglobin, in grams/deciliter & $10.45( \pm 2.10)^{\#}$ \\
\hline Pre-transplant glomerular filtration rate & $7.35(5.6,10.03)^{\&}$ \\
\hline $\begin{array}{l}\text { Pre-transplant anemia } \\
\text { absent } \\
\text { mild } \\
\text { severe }\end{array}$ & $\begin{array}{l}235(16.3)^{*} \\
181(12.6)^{*} \\
1022(71.1)^{*}\end{array}$ \\
\hline Loss of the graft before one year & $44(3.1)^{*}$ \\
\hline Mortality before one year & $39(2.7)^{*}$ \\
\hline
\end{tabular}

* Simple frequency (percentage), \& Median (Interquartile range 25.75), \# Mean (Standard deviation)

Table 2. Characteristics of population in relation to the presence of anemia, at one year of follow-up

\begin{tabular}{|c|c|c|c|}
\hline \multirow[b]{2}{*}{ Characteristics } & \multicolumn{3}{|c|}{$N=1355$} \\
\hline & $\begin{array}{l}\text { Anemia per year } \\
210(15.5)^{*}\end{array}$ & $\mathbf{P}$ & OR (IC 95\%) \\
\hline $\begin{array}{l}\text { Sex } \\
\text { Female } \\
\text { Male }\end{array}$ & $\begin{array}{l}103(7.6)^{*} \\
107(7.9)^{*}\end{array}$ & $0.01^{\wedge}$ & $0.70(0.52-0.94)$ \\
\hline $\begin{array}{l}\text { Donor } \\
\text { Cadaveric } \\
\text { Living }\end{array}$ & $\begin{array}{l}85(6.3)^{*} \\
125(9.2)^{*}\end{array}$ & $0^{\wedge}$ & $2.24(1.65-3.05)$ \\
\hline Age, in years & $31(25,42)^{\&}$ & $0.37 @$ & Does not apply \\
\hline Body mass index & $23.7(20.9,26.2)^{\&}$ & $0.74 @$ & Does not apply \\
\hline $\begin{array}{l}\text { Basal creatinine, in milligrams/ } \\
\text { deciliter }\end{array}$ & $10.7(7.8,13)^{\&}$ & $0.03^{\circledR}$ & Does not apply \\
\hline $\begin{array}{l}\text { Anemia basal } \\
\text { absent } \\
\text { mild } \\
\text { severe (Index) }\end{array}$ & $\begin{array}{l}30(2.2)^{*} \\
27(2)^{*} \\
153(11.3)^{*}\end{array}$ & $\begin{array}{l}0.65^{\wedge} \\
0.008^{\wedge}\end{array}$ & $\begin{array}{l}1.19(0.78-1.81) \\
1.02(0.65-1.59)\end{array}$ \\
\hline $\begin{array}{l}\text { Creatinine at the third month } \\
<2.0 \text { milligrams/deciliter } \\
\geq 2.0 \text { milligrams/deciliter }\end{array}$ & $\begin{array}{l}181(13.4)^{*} \\
29(2.1)^{*}\end{array}$ & $0^{\wedge}$ & $2.94(1.84-4.72)$ \\
\hline $\begin{array}{l}\text { Creatinine at the sixth month } \\
<2.0 \text { milligrams/deciliter } \\
\geq 2.0 \text { milligrams/deciliter }\end{array}$ & $\begin{array}{l}174(12.8)^{*} \\
36(2.7)^{*}\end{array}$ & $0^{\wedge}$ & $4.18(2.66-6.56)$ \\
\hline $\begin{array}{l}\text { Creatinine at the twelfth month } \\
<2.0 \text { milligrams/deciliter } \\
\geq 2.0 \text { milligrams/deciliter }\end{array}$ & $\begin{array}{l}162(12)^{*} \\
48(3.5)^{*}\end{array}$ & $0^{\wedge}$ & $5.55(3.66-8.42)$ \\
\hline
\end{tabular}

* Simple frequency (percentage), \& Median (Interquartile range 25.75), \# Mean (Standard deviation)

^Chi-square,@Spearman, ÇPearson

Some authors have reported slightly higher prevalence in populations other than ours (Spanish and North American). Such is the case of the publications by Hernández [26], El-Husseini [27] and Hirata [28], who found $3 \%$ to $4 \%$ for mortality and $7 \%$ to $8 \%$ for graft loss. 
Table 3. Logistic regression to predict anemia one year after kidney transplantation*

\begin{tabular}{|l|c|c|c|c|}
\hline Variable & $\mathbf{B}^{* *}$ & $\mathbf{p}$ & OR & $\mathbf{I C 9 5 \%}$ \\
\hline $\begin{array}{l}\text { Creatinine twelfth month dichotomous } 2.0 \\
\text { milligrams/deciliter }\end{array}$ & 1.45 & 0 & 4.26 & $2.61-6.94$ \\
\hline $\begin{array}{l}\text { Creatinine sixth month dichotomous 2.0 } \\
\text { milligrams/deciliter }\end{array}$ & 0.72 & 0.01 & 2.05 & $1.19-3.55$ \\
\hline Cadaveric Donor & 0.74 & 0 & 2.09 & $1.52-2.88$ \\
\hline Sex (Female) & 0.5 & 0.002 & 1.65 & $1.2-2.26$ \\
\hline
\end{tabular}

* Global model explanation percentage of $84.5 \%$, with Nagelkerke's $R 2$ of 0.11

** Beta coefficient

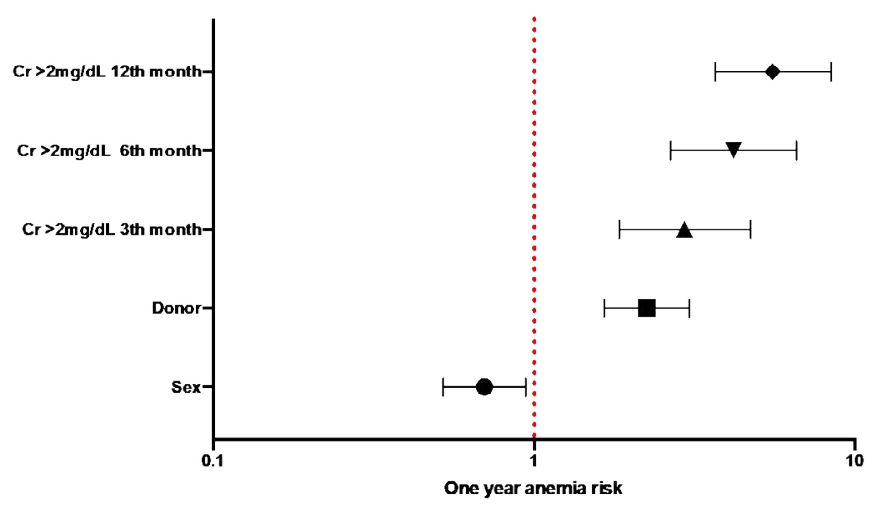

Figure 1. OR predicting one year post kidney transplantation anemia

However, the data observed by Hol y cols. [29], reached up to $11 \%$ mortality, depending on the type of donor (living or cadaveric), studying 500 cases, within a third level public concentration hospital, in Mexico. They also found 11 to $21 \%$ graft loss in the same period of time and, although the variables related to these outcomes were not analyzed in the present study, our prevalence was three times lower for mortality and seven times lower for loss of kidney graft.

This contrast, despite the similarities between the type of population included in both investigations, has no clear explanation. The same happens when comparing the results with Gondos [2], who in a multicenter collaborative study in Europe and the United States, when dividing the groups by ethnic origin, found, in more than 5,300 Hispanic Americans, a prevalence of $8.5 \%$ of loss of kidney graft, a year.

Perhaps, the selection of recipients, as well as the experience in the management and follow-up of patients within the transplant Units, may be factors to consider.

Regarding the presence of anemia, one year after transplantation, a $15.5 \%$ prevalence was found, a lower figure than that reported by Petrone [30] in Argentina (42\%), Huang (21\%) [13], Imoagene [31] and Turkowski (20\%) [22], but slightly higher than that described by Rosales (12.9\%) [32] in Mexico.

Petrone [30] found a significant difference when comparing anemia at one year, by sex, age and serum creatinine (dichotomous), however, only pediatric age and values above $2.0 \mathrm{mg} \mathrm{d} / \mathrm{L}$ were significant in its logistic regression. Their study does not specify pediatric age ranges, so it is unknown whether the values are different from ours, where there were no subjects under 16 years of age, a difference that could explain the lack of association between age and anemia in our case. On the other hand, in the bivariate analysis, there is agreement in our calculations of significance for sex and serum creatinine above $2.0 \mathrm{mg}$. The latter was also one of the significant variables in the logistic regression of both studies.
Imoagene [31], in the United States, indicated as a protective factor for anemia at one year, the male sex (OR 0.4, CI95\% 0.2-0.6), data that agrees with the risk that we identified for the female sex (OR 1.42, CI95 \% 1.05-1.91). Similar results were published by Mix [33] (OR 3.61 with 95\% CI 1.60-8.15) and other authors [33-36], including a recent article by Cruz-Santiago y cols. [37], within one of the hospitals that participated in our study. When comparing the median age with those of several studies $[5,10,13,15,16,31,38,39]$, it is up to 18 years younger, which is probably due to the fact that in our country there is a high incidence of chronic degenerative pathologies in young adults, leading to end-stage renal failure at an early age. Thus, in our analysis, no association was found between age and anemia, unlike Huang [13], who, including only patients with a living donor transplant, reported a protective effect at older age, with a HR 0.98 e $95 \%$ CI from 0.95 to 1.00 , in a group that did not exceed the age of 55 years.

In the rest of the variables, it is not possible to explain the difference of our results with those of other publications.

This is one of the few studies, in search of risk factors for postkidney transplant anemia, carried out in Latin America, which implies obtaining new data that strengthen the documented evidence for this condition. Furthermore, by addressing the sociodemographic characteristics of a population typical of the region, different from most previous publications, it allows making comparisons in this regard. On the other hand, it joins a short list of investigations that specifically analyze PTA during the first year. Most of the studies that have investigated the persistence of this post-renal transplant pathology have carried out a general analysis on a longer time line and without focusing on the first months of late PTA.

Our study can be considered numerous, based on the subjects included, compared to several investigations in which one or two hospital centers have participated. This can be explained by the fact that the Units where the recruitment was carried out are public concentration hospitals, in addition to the fact that the total population was considered for 5 years. This represents a strength, as selection bias was avoided.

\section{Study limitations}

Among the limitations of our research, in addition to the fact that it was a retrospective and descriptive study, is the failure to include significant variables in the analysis in other reports, such as immunosuppressive treatment $[10,16,22,31,38,39]$, comorbidities [13$17,31]$, intraoperative bleeding [16,40], cold ischemia time, delayed graft function [22,40], drug interaction [38] and treatment of anemia $[10,17,19,22,38,39]$; furthermore, the follow-up was relatively short for late PTA, compared with existing articles, where subjects have been observed for longer periods $[10,12,14,38,39]$, reaching up to more than 10 years [8].

\section{Conclusion}

Height, pre-transplant creatinine, as well as creatinine at the third, sixth and twelfth month are associated with the presence of anemia one year after kidney transplantation, in addition, there is a greater risk in women, in those who receive the organ of cadaveric origin and in presence of serum creatinine above $2.0 \mathrm{mg} / \mathrm{dL}$ after transplantation, during the first year.

It is convenient to carry out investigations where the limitations of the present study are solved, in order to corroborate the results obtained, since, although some variables studied coincide with what was 
previously published, others differ notably. This could be achieved with methodological designs that include a greater number of variables that influence the outcome, multicenter studies, and follow-ups for longer periods of time. On the other hand, the study of factors associated with mortality and graft loss in this type of patient can be a line of research to be developed, in a complementary way.

\section{Acknowledgement}

To the Mexican Institute of Social Security, to the Renal Transplant Units of the National Medical Center XXI Century and the National Medical Center Specialties Hospital "La Raza", the IMSS Clinical Research Training Center. To our collaborators. To our families. A special thanks to all transplant patients in our Institution, to whom we owe ourselves professionally.

\section{Conflict of interests}

The authors of this article declare that they have no conflict of interest in the results obtained.

\section{Financing}

The present study was developed without funding from any institution. The resources used were provided by the authors.

\section{References}

1. Martín P, Errasti P (2006) Trasplante renal. Kidney transplant. An Sist Sanit Navar 29: 79-92. [Crossref]

2. Adam G, Döhler B, Brenner H, Opelz G (2013) Kidney Graft Survival in Europe and the United States: Strikingly Different Long-Term Outcomes, Transplantation 95: 267274 [Crossref]

3. Tonelli M, Wiebe N, Knoll G, Bello A, Browne S, et al. (2011) Systematic review: Kidney transplantation compared with dialysis in clinically relevant outcomes. $\mathrm{Am} \mathrm{J}$ Transplant 11: 2093-2109. [Crossref]

4. Purnell TS, Auguste P, Crews DC, Lamprea-Montealegre J, Olufade T, et al. (2013) Comparison of life participation activities among adults treated by hemodialysis, peritoneal dialysis, and kidney trans- plantation: A systematic review. Am J Kidney Dis 62: 953-973. [Crossref]

5. Merion RM, Goodrich NP, Johnson RJ, McDonald SP, Russ GR, et al. (2018) Kidney transplant graft outcomes in 379257 recipients on 3 continents. Am J Transplant 18: 1914-1923. [Crossref]

6. Cortázar-Benítez L, González-Patiño M, Barbosa-Zamora A, Pardinas-Llergo M, Rodríguez-Weber F, et al. (2015) Infecciones tempranas postrasplante renal. Med Int Méx 31: 559-566.

7. Yuste J, Del Pozo J, Quetglás E, Azanza J (2006) Infecciones más comunes en el paciente trasplantado. An Sist Sanit Navar 29: 175-206.

8. Kovacs G, Devercelli G, Zelei T, Hirji I, Voko' Z, et al. (2020) Association between transplant glomerulopathy and graft outcomes following kidney transplantation: A meta-analysis. PLoS ONE 15: e0231646. [Crossref]

9. Fishman JA (2017) Infection in organ transplantation. Am J Transplant 17: 856-879. [Crossref]

10. Majernikova M, Rosenberger J, Prihodova L, Marcelli D, Roland R, et al. (2015) Anemia has a negative impact on self-rated health in kidney transplant recipients with well-functioning grafts: findings from an 8-year follow-up study. Qual Life Res 25 1-10. [Crossref]

11. Romero R, Alonso A, Amenábar J, Caparrós S, Díaz J, et al. (2011) Etiopatogenia, prevalencia y factores de riesgo de la anemia del trasplante renal. Nefrología Sup Ext 2: 3-7.

12. Martínez Z, Chew-Wong M, Cabral AR, Alejandro (2018) Anemia postrasplante renal, su efecto en la función y en la sobrevida del injerto. Lux Médica 39:19-28.

13. Huang Z, Song T, Fu L, Rao Z, Zeng D, et al. (2015) Post-renal transplantation anemia at 12 months: prevalence, risk factors, and impact on clinical outcomes. Int Urol Nephrol 47: 1577-1585. [Crossref]
14. Schjelderup P, Dahle DO, Holdaas H, Mjøen G, Nordby G, et al. (2013) Anemia is a predictor of graft loss but not cardiovascular events and all-cause mortality in renal trans- plant recipients: follow-up data from the ALERT study. Clin Transplant 27: E636-E43. [Crossref]

15. Gafter-Gvili A, Cohen E, Avni T, Grossman A, Vidal L, et al. (2015) Predicting the emergence of anemia - A large cohort study. Eur J Intern Med 26: 338-343. [Crossref]

16. Schechter A, Gafter-Gvili A, Shepshelovich D, Rahamimov R, Gafter U, et al. (2019) Posttransplantation anemia: causes, severity and their association with graft and patient survival. BMC Nephrol. (In press).

17. Heinze G, Mitterbauer C, Regele H, Kramar R, Winkelmayer WC, et al. (2006) Angiotensin-converting enzyme inhibitor or an- giotensin II type 1 receptor antagonist thera- py is associated with prolonged patient and graft survival after renal transplantation. J Am Soc Nephrol 17: 889-899. [Crossref]

18. Jimeno L, Rodado R, Campos M, Lanuza M (2005) Iron deficiency - an underrecognized problem in nonanemic and erythrocytic kidney transplant recipients: risks and effects of ACEI and of iron treatment. Transplant Proc 37: 1007-1008. [Crossref]

19. Zheng S, Coyne DW, Joist H, Schuessler R, Godboldo-Brooks A, et al. (2009) Iron deficiency anemia and iron losses after renal transplantation. Transpl Int 22: 434-440. [Crossref]

20. Sun CH, Ward HJ, Paul WL, Koyle MA, Yanagawa N, et al. (1989) Serum erythropoietin levels after renal transplantation. N Engl J Med 321: 151-157. [Crossref]

21. Saito S, Fujiwara T, Sakagami K, Matsuno T, Tanaka N (1998) Anemia following renal transplantation. Transplant Proc 30: 3025-3026. [Crossref]

22. Turkowski-Duhem A, Kamar N, Cointault O, Lavayssiere L, Ribes D, et al. (2005) Predictive factors of anemia within the first year post renal transplant. Transplantation 80: 903-909. [Crossref]

23. Iwamoto H, Nakamura Y, Konno O, Yokoyama T, Kihara Y, et al. (2014) Correlation Between Post Kidney Transplant Anemia and Kidney Graft Function. Transplant Proc 46: 496-498.

24. Marcén R, Galeano C, Fernández-Rodríguez A, Jiménez S, Teruel J, et al. (2012) Anemia at 1 Year After Kidney Transplantation Has a Negative Longterm impact on graft and patient outcomes. Transplant Proc 44: 2593-2595. [Crossref]

25. Majernikova M, Rosenberger J, Prihodova L, Jarcuskova M, Roland R, et al. (2017) Posttransplant Anemia as a Prognostic Factor of Mortality in Kidney-Transplant Recipients. BioMed Res Int 2017: 1 6987240. [Crossref]

26. http://www.revistanefrologia.com/es-monografias-nefrologia-dia-articulo-resultadosglobales-del-trasplante-renal-58

27. El-Husseini A, Aghil A, Ramirez J, Sawaya B, Rajagopalan N, et al. (2017) Outcome of kidney transplant in primary, repeat, and kidney-after-nonrenal solid-organ transplantation: 15-year analysis of recent UNOS database. Clin Transplant 31: 11. [Crossref]

28. Hirata, Masaru, Cho, Yong W.; Cecka, J Michael; Terasaki, Paul I. Patient death after renal transplantation an analysis of its role in graft outcome. Transplantation 61: 14791483. [Crossref]

29. Holm CA, Jiménez DA, Hernández DM (2002) Trasplante renal de donador vivo relacionado y donador cadáver: experiencia con 500 casos. Cir Gen 24: 116-123.

30. Petrone H, Arriola M, Re L, Taylor F, Bruzzone M, et al. National survey of anemia prevalence after kidney transplantation in Argentina. Transplant Proc 42: 288-290. [Crossref]

31. Imoagene-Oyedeji AE, Rosas SE, Doyle AM, Goral S, Bloom RD (2006) Posttransplantation Anemia at 12 Months in Kidney Recipients Treated with Mycophenolate Mofetil: Risk Factors and Implications for Mortality. J Am Soc Nephrol 17: 3240-3247. [Crossref]

32. Rosales Morales KB, Pérez RE, Cancino López JD, Díaz ER, Pérez MJC, et al Anemia and Erythrocytes: Behavior and Prevalence 1 Year After Kidney Transplant Transplantation Proc 52: 1169-1172. [Crossref]

33. Mix TCH, Waqar Kazmi, Samina Khan, Robin Ruthazer, Richard Rohrer, et al. (2003) Pereira, Annamaria T. Kausz. Anemia: A Continuing Problem Following Kidney Transplantation. Am J Transplant 3: 1426-1433. [Crossref]

34. Shibagaki Y, Shetty A. Anaemia is com- mon after kidney transplantation, especially among African Americans. Nephrol Dial Transplant 19: 2368-2373. [Crossref]

35. Einollahi B, Lessan-Pezeshki M, Rostami Z, Kalantar E, Afshar R, et al. (Anemia after kidney transplantation in adult recipients: prevalence and risk factors. Transplant Proc 43: 578-580. [Crossref]

36. Lim AKH, Kansal A, Kanellis J (2018) Factors associated with anaemia in kidney transplant recipients in the first year after transplantation: a cross-sectional study. $B M C$ Nephrol 19: 252. 
37. Cruz-Santiago J, Velázquez-Zambrano C, Escamilla-Galindo PA, Díaz-Rosas G, RojasRodríguez FO, et al. (2020) Change in the Pattern of Posttransplantation Anemia in Kidney Receptors: Sex Role in Recipients and Type of Donor. Transplant Proc 52: 1163-1168. [Crossref]

38. Vanrenterghem Y, Ponticelli C, Morales JM, Abramowicz D, Baboolal K, et al. (2003) Prevalence and management of anemia in re- nal transplant recipients: a European survey. Am J Transplant 3: 835-845. [Crossref]
39. Yorgin PD, Scandling JD, Belson A, Sanchez J, Alexander SR, et al. (2002) Late posttransplant anemia in adult renal transplant recipients. An under-recognized problem? Am J Transplant 2: 429-435. [Crossref]

40. Tsuchimoto A, Masutani K, Haruyama N, Nagata M, Noguchi H, et al. (2013) Renal interstitial fibrosis in 0-hour biopsy as a predictor of post-transplant anemia. $\mathrm{Am} \mathrm{J}$ Nephrol 38: 267 [Crossref]

Copyright: (C2021 Adame IQ. This is an open-access article distributed under the terms of the Creative Commons Attribution License, which permits unrestricted use, distribution, and reproduction in any medium, provided the original author and source are credited. 